\title{
Physiochemical Characterization and Field Assessment of Lettuce Chlorosis Virus
}

Jennifer McLain, Department of Plant Pathology, University of California, Riverside 92521; Steven Castle, USDA-ARS, Phoenix, AZ; Gerald Holmes, Department of Plant Pathology, North Carolina State University, Raleigh; and Rebecca Creamer, Department of Plant Pathology, University of California, Riverside 92521

\begin{abstract}
McLain, J., Castle, S., Holmes, G., and Creamer, R. 1998. Physiochemical characterization and field assessment of lettuce chlorosis virus. Plant Dis. 82:1248-1252.

Lettuce chlorosis virus (LCV) was purified and partially characterized, and polyclonal antisera were produced and used to assess disease in the field. The antisera reliably detected LCV by indirect enzyme-linked immunosorbent assay (ELISA) in Nicotiana benthamiana. In Western blots, the LCV antisera distinguished between LCV and lettuce infectious yellows virus (LIYV)-infected plants. LCV particle lengths in partially purified preparations, as observed by transmission electron microscopy, were variable, with the majority between 750 and $950 \mathrm{~nm}$ long. A single, high molecular weight dsRNA and several lower molecular weight dsRNAs were isolated from LCV-infected $N$. benthamiana. A single RNA isolated from purified virion preparations was estimated to be 8,625 nucleotides long and was suspected to be the genomic RNA of LCV. LCV was present in experimental field plots in Holtville, California, during the lettuce growing seasons of 1995 to 1997 . The percentage of symptomatic plants and yield of lettuce heads treated with insecticide, as well as dsRNA and ELISA reactions for the plots, are reported. A dsRNA consistent in size with LCV was isolated from four weed species in the Imperial Valley of California.
\end{abstract}

Yellowing symptoms of weeds, lettuce, and sugar beets have occurred in the Imperial Valley of California since the 1980s and were shown to be caused by lettuce infectious yellows virus (LIYV) (8). To ascertain if LIYV was the sole cause of these symptoms in recent years, stunted lettuce heads with brittle leaves and interveinal chlorosis were collected from fields in the Imperial Valley in the winter of 1992-93. These symptomatic plants did not react with LIYV antiserum in indirect enzyme-linked immunosorbent assay (ELISA). Furthermore, a single dsRNA of high molecular weight was isolated from symptomatic lettuce, but not from nonsymptomatic lettuce of the same variety. The agent causing the symptoms could be easily transmitted between lettuce and other plants by the silverleaf whitefly, $B e$ misia argentifolii (Bellows \& Perring), whereas LIYV is not easily transmitted by the silverleaf whitefly (4). The diseased plants collected were hypothesized to be infected with a new virus.

Duffus et al. (9) initially characterized this new virus, named lettuce chlorosis virus (LCV), by showing differences between LCV and LIYV in whitefly transmission and host range. This paper reports

Corresponding author: Rebecca Creamer

E-mail: rebecca.creamer@ucr.edu

Accepted for publication 31 July 1998.

Publication no. D-1998-0827-01R

(C) 1998 The American Phytopathological Society the further characterization of LCV and presents information on its epidemiology and control.

\section{MATERIALS AND METHODS}

Virus acquisition and maintenance. LCV was acquired from symptomatic lettuce (Lactuca sativa L.) from the Imperial Valley of California in the winter of 199293 and in April 1996. The ability of whiteflies to transmit LCV was tested by placing adult $B$. argentifolii on symptomatic lettuce leaves for $24 \mathrm{~h}$ prior to transfer to healthy, greenhouse-grown Nicotiana benthamiana Domin. for a 48-h inoculation feeding. Whiteflies were killed with insecticide (resmethrin), and the plants were placed in the greenhouse for symptom development. Virus source plants were subsequently maintained by $B$. argentifolii transmission to $N$. benthamiana plants.

$B$. argentifolii whiteflies were maintained on Phaseolus vulgaris L. 'Top Crop'. The colony was initially obtained from Thomas Perring (Riverside, CA), where it was started with nymphs of whitefly females. The whiteflies were collected from cauliflower (Brassica oleracea L. var. botrytis) plants in the Imperial Valley in 1991 and were verified as B. argentifolii (15).

Virion purification. The procedure of Klaassen et al. (11) was used to purify LCV from infected $N$. benthamiana (1 month postinfection), which was ground in liquid nitrogen with a mortar and pestle. were used for virus purifications utilized in Sucrose-cesium sulfate gradients $(3 \mathrm{ml})$ RNA size determination (10). Virus was recovered from the sucrose-cesium gradients using an ISCO Model 640 Density Gradient Fractionator (Lincoln, NE). The gradients were not carried out for virus purifications used for antisera production and particle observations.

Particle observations. Partially purified virion preparations were placed on Formvar heavy carbon-coated grids stained with $2 \%$ uranyl-acetate and examined with a Hitachi H-600 transmission electron microscope. The length of 62 particles was measured. Calculations were made using a grid replica photographed together with the particles.

Antisera production. Purified preparations of LCV at a concentration of $\geq 0.6 \mathrm{mg}$ of virus were used for antisera production in rabbits. The initial injection was made using equal volumes of Freund's complete adjuvant and virus preparation. Three subsequent injections were made at 2-week intervals using equal volumes of Freund's incomplete adjuvant and virus preparation. Rabbits were bled 2, 5, and 7 weeks after the initial injection. IgG was purified using a protein A-Sepharose column (16).

Serological analysis. ELISAs were performed as antigen coated indirect assays essentially as described previously (7). Plant extracts, LCV IgG, goat anti-rabbit IgG alkaline phosphatase conjugate (GARG-conjugate) (Sigma, St. Louis, $\mathrm{MO})$, and $p$-nitrophenylphosphate substrate were each incubated for approximately $2 \mathrm{~h}$ at $37^{\circ} \mathrm{C}$ on Immulon 2 polystyrene plates (Dynatech, Chantilly, VA). Plant samples collected with a no. 15 cork borer were inserted between rollers of a sap expressor (Ravenel Specialties Co., Seneca, SC) and rinsed with coating buffer $(0.05 \mathrm{M}$ sodium carbonate, $\mathrm{pH}$ 9.6) until $2 \mathrm{ml}$ of sap-buffer were collected. LCV IgG was utilized at a 1:10,000 dilution, and GARG-conjugate was used at a 1:2,000 dilution. Absorbance measurements $\left(A_{405 \mathrm{~nm}}\right)$ were taken when positive samples had readings of at least 1.0. Samples were considered positive when absorbencies were greater than the mean of three healthy controls +3 standard deviations.

Western blots were done as described previously (6), using $0.2 \mathrm{~g}$ of tissue per sample. Low molecular weight protein standards (Bio-Rad, Hercules, CA) were used for size estimation. Samples were electrophoresed through a 5\% stacking and $15 \%$ resolving sodium dodecyl sulfate (SDS)-polyacrylamide $(16)$ gel $(7 \times 10 \mathrm{~cm})$ at $100 \mathrm{~V}$ for $1 \mathrm{~h}$ in a Mini-Protean II sys- 
tem (Bio-Rad). Proteins were electroblotted onto Immobilon-P (PVDF) (Millipore, Bedford, MA). LCV antisera was crossabsorbed with healthy $N$. benthamiana. Leaf tissue $(0.25 \mathrm{~g})$ was homogenized and diluted with $20 \mathrm{ml}$ of TBST buffer $(10 \mathrm{mM}$ Tris, $\mathrm{pH} 8.0,150 \mathrm{mM} \mathrm{NaCl}, 0.05 \%$ Tween 20). This solution was centrifuged at 7,100 $\times g$ for $5 \mathrm{~min}$, and the supernatant was mixed with the antisera. LCV and LIYV antisera were used at a 1:10,000 and 1:1500 dilutions, respectively. Goat antirabbit alkaline phosphatase conjugate (Sigma) was diluted at a 1:2,000 concentration.

dsRNA analysis. dsRNA was purified by a method similar to Valverde et al. (18), with slight modifications as described by Creamer (6). DNA was removed from dsRNA preparations by addition of $1 \mu \mathrm{l}$ of RQ1 DNase (Promega, Madison, WI) with $0.0025 \mathrm{M} \mathrm{MgCl}_{2}$ followed by incubation at $37^{\circ} \mathrm{C}$ for $1 \mathrm{~h}$. Samples were stored at $4^{\circ} \mathrm{C}$ until use. dsRNA samples were electrophoresed on $6 \%$ polyacrylamide gels at $100 \mathrm{~V}$ for $3 \mathrm{~h}$. Gels were stained with ethidium bromide at $1 \mu \mathrm{g} / \mathrm{ml}$ for $20 \mathrm{~min}$ prior to photography. Four gels were used to estimate the size of the LCV dsRNA.

RNA size analysis. Nucleic acids were isolated from a purified LCV virion preparation (from infected $N$. benthamiana) immediately after purification by the addition of RNA extraction buffer $(0.1 \mathrm{M}$ Tris$\mathrm{HCl}, \mathrm{pH} 8.0,5 \mathrm{mM}$ EDTA, $1.5 \%$ SDS, and $100 \mu \mathrm{g}$ of proteinase $\mathrm{K}$ per $\mathrm{ml}$ ) (11) and shaking for $10 \mathrm{~min}$ at room temperature. Nucleic acids were separated from proteins by two extractions with phenol:chloroform (1:1, vol/vol) followed by one extraction with chloroform:isoamyl alcohol (24:1, vol/vol). Nucleic acids were ethanol precipitated, and the purified RNA was stored at $-20^{\circ} \mathrm{C}$. dsRNA from LCV-infected $N$. benthamiana was also resuspended in sterile water and treated similarly to nucleic acid isolated from purified virions.

For denaturing RNA gels, RNA preparations were denatured with glyoxal and dimethylsulfoxide (13), separated on a $1 \%$ agarose gel, and electrophoresed at $60 \mathrm{~V}$ for $3.5 \mathrm{~h}$. Gels were stained with ethidium bromide $(1 \mu \mathrm{g} / \mathrm{ml})$ in $0.1 \mathrm{M}$ ammonium acetate for $20 \mathrm{~min}$ and photographed.

Field trials. Lettuce field trials were established on two planting dates each in 1995-96 and 1996-97 seasons in Holtville, California. The first plot of the 1995-96 season was planted on 13 September 1995 with cultivars Acacia, Empire, Gilaben, and Fallgreen; the second on 13 October 1995 with cultivars Acacia, Empire, Winterhaven, and New Dominion. The first plot of the 1996-97 season was planted on 17 September 1996 with Empire lettuce and the second on 15 October 1996 with Winterhaven lettuce. In September 1995, plants given a treatment of imidacloprid (Admire, used at 2.3 liters/ha [32 oz./acre]) at planting were compared with untreated plants. For the October 1995 planting, three treatments were utilized: untreated, imidacloprid applied at planting, and imidacloprid applied at planting followed by weekly bifenthrin (Capture, used at label rate) sprays from 46 days after planting to 30 days prior to harvest. The 1995-96 trials were split-plot designs in which the field was divided into four blocks. The block divisions ran along the length of the beds. Each insecticide treatment was randomized within each block. Varieties were randomized along bed lengths. Experimental units were $6.1 \mathrm{~m} \mathrm{(20}$ ft) long and two beds wide. Bordering lettuce surrounded the plot by $3.1 \mathrm{~m}(10 \mathrm{ft})$ on each end of the beds and two beds on each side of the plot.

The 1996-97 trials were similar to those of the previous year with several minor modifications. The experimental units were

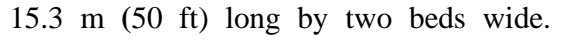
Bordering lettuce extended at least $4.6 \mathrm{~m}$ $(15 \mathrm{ft})$ on the ends of the beds and two beds on the side of the plot. Each plot had one lettuce variety per planting date. In both years, standard practices for growing lettuce were utilized. The beds were 106.7 $\mathrm{cm}$ (42 in) apart. Lettuce was sprinkler irrigated to germination and then furrow irrigated. Plants were thinned to $30.5 \mathrm{~cm}$ (1 ft) spacing.

Data collection. Plants judged to be symptomatic were collected and tested by dsRNA analysis (1995-96 season) or ELISA (1996-97 season). Leaves were collected and assayed 1 month after planting and at harvest. The percentage of symptomatic plants was also determined for all plots at harvest. Average lettuce head weights were determined by weighing all marketable heads in a $6.1 \mathrm{~m}$ (20-ft) length of one bed. Individual head weights, symptom assessments, and ELISAs were additionally carried out on 160 lettuce heads collected at random by walking a "W" pattern through each sampling unit of the October 1996 planted trial at harvest.
Weed host collection. Weeds were collected from areas surrounding lettuce fields in the Imperial Valley and tested for LCV by dsRNA analysis.

\section{RESULTS}

Purification. Using an extinction coefficient of $2(\mathrm{mg} / \mathrm{ml})^{-1} \mathrm{~cm}^{-1}$ for beet yellows virus (1), virus yield was estimated to be $2.4 \mu \mathrm{g} / \mathrm{g}$ for pregradient preparations and $0.76 \mu \mathrm{g} / \mathrm{g}$ for postgradient preparations.

Numerous particles were observed in partial purifications of $N$. benthamiana. Many particles were obviously broken or were attached end-to-end. Only particles that appeared to be of single-unit length and unbroken were measured. Particle measurements varied considerably, with the modal length between 750 and $950 \mathrm{~nm}$.

Serological analyses. The LCV antisera reacted positively with purified LCV and LCV-infected $N$. benthamiana, and did not react with healthy $N$. benthamiana in ELISA. LCV-infected $N$. benthamiana typically reacted 7.1-fold higher than healthy background absorbance in ELISAs when the antisera was cross-absorbed with healthy $N$. benthamiana. LCV antisera detection of LCV in cheeseweed (Malva parviflora) also correlated well with symptoms and consistently produced strong reactions. Preimmune sera did not react to purified LCV or LCV-infected plants. In ELISAs, LCV antisera reacted equally well with LCV or LIYV-infected lettuce.

In Western blot analyses, LCV purified from infected $N$. benthamiana and greenhouse-infected $N$. benthamiana tissue reacted positively to LCV antiserum (Fig. 1, lane 3). A disease-specific protein of approximately $32 \mathrm{kDa}$ was consistently observed in blots. LCV antiserum did not react with LIYV-infected plants. The LIYV antiserum appeared to be less specific and reacted strongly to both LIYVand LCV-infected plants (Fig. 1, lanes 7 and 8). Reactions to symptomatic field

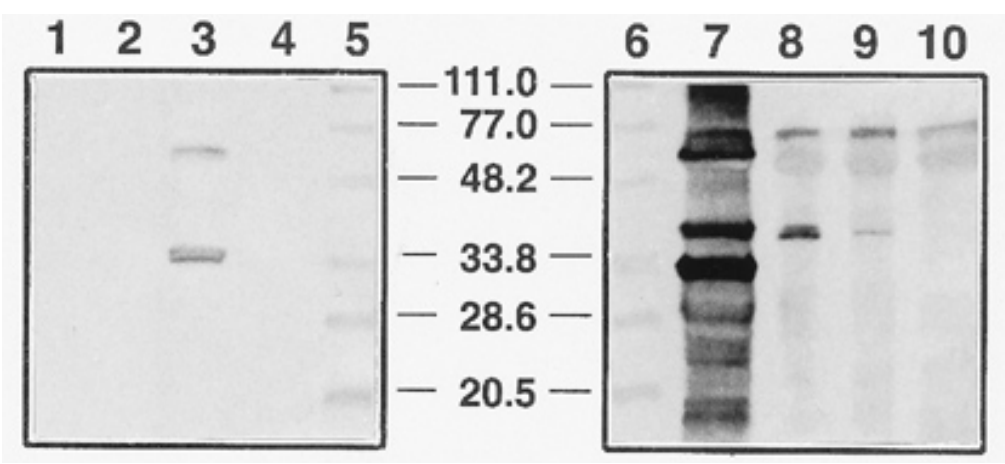

Fig. 1. Western blot analysis of lettuce chlorosis virus (LCV) proteins. Lanes 1 to 5 were probed with LCV antiserum, and lanes 6 to 10 with lettuce infectious yellows virus (LIYV) antiserum. Lanes 1 and 10, healthy Nicotiana benthamiana; lanes 2 and 9, healthy $N$. clevelandii; lanes 3 and 8, LCVinfected $N$. benthamiana; lanes 4 and 7, LIYV-infected $N$. clevelandii; and lanes 5 and 6 , protein molecular weight standards. Total proteins were separated on $15 \%$ sodium dodecyl sulfate-polyacrylamide gel electrophoresis (SDS-PAGE) gels and electroblotted onto PVDF membranes. Molecular weights of the protein standards are indicated between the blots. 
lettuce were considerably weaker than to LCV-infected $N$. benthamiana (data not shown).

RNA analyses. The dsRNA profile of LCV revealed a single high molecular weight dsRNA and several lower molecular weight dsRNAs (Fig. 2). The largest dsRNA consistently migrated below the replicative form of tobacco etch virus (9,800 nucleotides, 18) and beet yellows virus (15,500 nucleotides, 2$)$, and above the replicative forms of tomato infectious chlorosis virus $(7,400$ and 7,800 nucleotides, 20) and tobacco mosaic virus $(6,400$ nucleotides, 18), and was estimated to be between 8,100 and 8,900 nucleotides.

Denatured high molecular weight LCV dsRNA (data not shown) and RNA extracted from LCV virion preparations (Fig. 3 ) each gave a single band of nucleic acid with an estimated size of 8,625 nucleotides.

Field trials: symptom expression. LCV infection in the field trials in the 1995-96 and 1996-97 growing seasons was confirmed by symptoms (interveinal chlorosis and thickened leaves) and positive ELISA readings or dsRNA banding pattern. Significant differences in the percentage of symptomatic lettuce plants were observed among the trials. In 1995-96, an average of $13.4 \%$ (Table 1) and $24.3 \%$ (Table 2) of the untreated lettuce heads in the first and second planted trials, respectively, showed LCV symptoms. In contrast, in 1996-97, an average of only 2.1 and
$0.2 \%$ (Table 3) of the untreated lettuce in the first and second planted trials showed LCV symptoms.

All varieties of lettuce tested showed disease symptoms, although the severity of symptoms differed slightly among varieties. Insecticide treatment also influenced the amount of disease symptoms. In the September 1995 planted trial, only in Acacia were significantly more symptoms found in the untreated than in insecticidetreated plants (Table 1). However, in the October 1995 planted trial, untreated heads of all lettuce varieties showed significantly more disease symptoms than the insecticide-treated heads (Table 2). Similar results were found in the September 1996 planted trial (Table 3).

Field trials: yield effects. Lettuce yield was improved by insecticide treatment in trials in 1995 and 1996. Average head weights were significantly different between the insecticide-treated and untreated heads in the September 1996 planted trial (Table 3) and for Acacia and Empire varieties in the October 1995 planted trial (Table 2). Average head weight was not determined for the September 1995 planted trial since the lettuce had poor growth and patchy distribution due to cultural problems. The October 1996 planted trial, which had only minimal whitefly pressure, did not show significant differences in yield between treatments (Table 3). The average head weight differences found between untreated and insecticide-treated

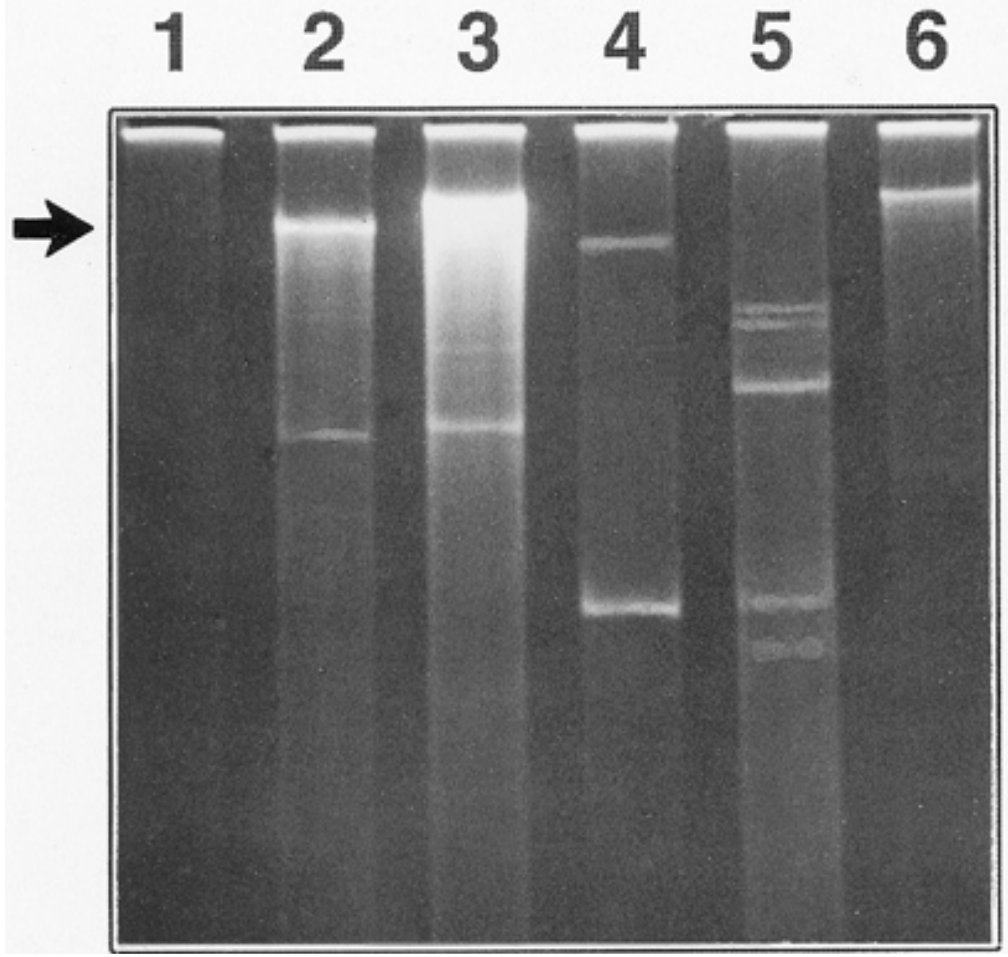

Fig. 2. Analysis of dsRNAs in a $6 \%$ polyacrylamide gel stained with ethidium. Lane 1, healthy Nicotiana benthamiana; lane 2, lettuce chlorosis virus (LCV) in N. benthamiana; lane 3, beet yellows closterovirus in Tetragonia expansa; lane 4, tobacco mosaic tobamovirus with satellite in $N$. tabacum; lane 5, cucumber mosaic cucumovirus in N. tabacum; and lane 6, citrus tristeza closterovirus in Citrus cv. Madam Vinous. Predominant LCV dsRNA indicated by arrow. heads correlated well with the percentage of LCV-symptomatic plants in the September 1996 planted trial (Table 3). No significant differences in yield were found among the different lettuce varieties in either 1995 planted trials.

Field trials: correlation of symptoms, yield, and disease. In a dsRNA analysis of 30 heads harvested from the September 1995 planted trial, $40.9 \%$ of symptomatic lettuce heads and $4.8 \%$ of the asymptomatic heads showed a dsRNA banding pattern consistent with LCV. For 160 lettuce heads randomly harvested from the September 1996 planted trial, the weights of the individual lettuce heads were compared with the LCV symptoms they displayed. Lettuce heads that showed pronounced LCV symptoms gave significantly

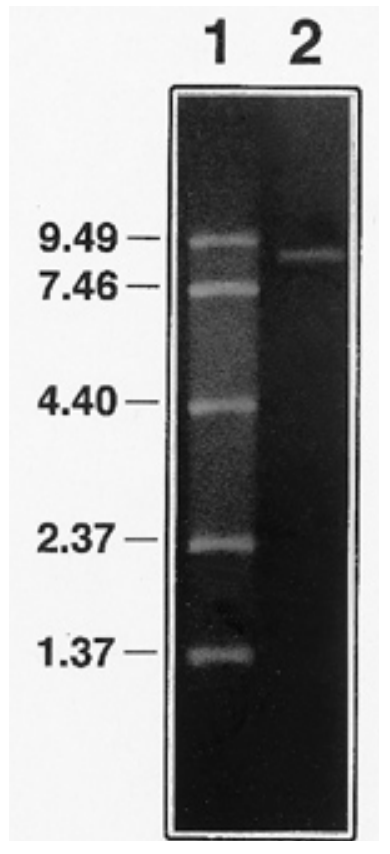

Fig. 3. Analysis of glyoxal denatured of RNA from purified lettuce chlorosis virions. A 1\% agarose gel stained with ethidium. Lane 1 , RNA standards, and lane 2, RNA isolated from virion purification of Nicotiana benthamiana showing its molecular weight to be approximately $8.6 \mathrm{~kb}$. Molecular weights of the RNA standards are indicated at the left of the gel.

Table 1. Influence of insecticide treatment on lettuce chlorosis virus (LCV) symptoms in the September 1995 planted trial

\begin{tabular}{lcc}
\hline & \multicolumn{2}{c}{$\begin{array}{c}\text { Plants with LCV } \\
\text { symptoms (\%) }\end{array}$} \\
\cline { 2 - 3 } Lettuce variety & Untreated & Imidacloprid \\
\hline Acacia & $16.0(5)$ & $6.9(2)^{\mathrm{b}}$ \\
Empire & $7.3(5)$ & $7.1(6)$ \\
Fallgreen & $10.3(7)$ & $13.4(10)$ \\
Gilaben & $19.9(14)$ & $15.4(13)$ \\
Treatment means & $13.4(9)$ & $10.7(9)$ \\
\hline
\end{tabular}

a Mean of four blocks. Standard deviation is indicated in parenthesis.

b Treatment is significantly different from untreated control at $P=0.05$ using Fisher's LSD for the variety indicated. 
lower mean head weights (486.6 g) than those not showing symptoms $(697.0 \mathrm{~g})$. The average head weight for ELISA-positive heads $(632.6 \mathrm{~g})$ was not significantly different from that of ELISA-negative heads $(661.0 \mathrm{~g})$.

Weed hosts. Of the weeds tested, dsRNA consistent in size for LCV was isolated from five plant species, Physalis wrightii (Wright's ground cherry), Conyza canadensis (mare's tail), Lactuca serriola (prickly lettuce), Solanum eleaegnifolium (silverleaf nightshade), and Helianthus nutalli (sunflower). In the fall, sunflower and Wright's groundcherry were often found infested with large whitefly populations. The prickly lettuce plants had few or no whitefly colonies; however, whitefly adults were observed on this species.

\section{DISCUSSION}

Based on particle morphology and symptoms, LCV resembles other closteroviruses (2). The symptoms of LCV and LIYV in lettuce are generally indistinguishable. The particle length estimate of 750 to $950 \mathrm{~nm}$ for LCV agrees with the 700 to $800 \mathrm{~nm}$ length from partially purified preparations and the 800 to $850 \mathrm{~nm}$ from leaf sap reported by Duffus et al. (9). It is difficult to make accurate estimates of closterovirus particle length, because the long, flexuous rods break during purification due to stresses such as mechanical sheering and $\mathrm{pH}$ and osmotic changes.

Western blot analyses distinguished between LCV and LIYV. The 32-kDa protein identified by LCV antiserum is likely the LCV capsid protein, which is similar in size to the $32-\mathrm{kDa}$ capsid protein of beet pseudo yellows closterovirus (20) but larger than the $28 \mathrm{kDa}$ found for LIYV (11). Although LCV antisera reliably detected LCV in plants such as $N$. benthamiana and M. parviflora by ELISA, LCV could not be differentiated from LIYV in lettuce in which these viruses occur in low concentration. Therefore, in locations where LCV and LIYV might both be present, LCV detection using PCR or nucleic acid hybridization (17) would allow a more specific virus identification. However, since LIYV has not been found in the field in California for almost a decade, the use of ELISA for LCV detection can be easily justified.
While aphid-transmitted closteroviruses possess a monopartite RNA genome, whitefly-transmitted closteroviruses such as LIYV (11,12) and TICV (20) contain bipartite genomes. Other whitefly-transmitted clostero-like viruses such as beet pseudo yellows virus appear to have a monopartite genome (3). LCV virions also appear to contain a single RNA species of 8,625 nucleotides, which is similar in size to that of 8,500 nucleotides reported for the largest LIYV RNA (11). The dsRNA profile of LCV shows one high molecular weight band and several lower molecular weight bands, which presumably correspond to the replicative form of the genomic RNA and subgenomic RNAs, respectively. Only one single high molecular weight dsRNA was observed for $\mathrm{LCV}$ on polyacrylamide gels in which the two high molecular weight dsRNA bands TICV separated from each other, suggesting that LCV has only the single genomic RNA or two RNAs with similar sizes.

In the lettuce trials, there were significant differences in the percentage of symptomatic plants in insecticide-treated plots when compared with untreated lettuce in the October 1995 planted and September 1996 planted trials. Significant differences were found only in Acacia variety in the September 1995 planted trial, and no differences were found in the October 1996 planted trial. These results are likely due to differences in whitefly numbers in the plots during the different trials or infection rates too low for valid comparison.

Feeding by silverleaf whitefly nymphs can cause chlorosis and stunting in lettuce independent of the presence of the virus. Palumbo et al. (14) reported that head let- tuce is particularly susceptible to sweetpotato whitefly feeding injury, especially during September and October when populations migrate onto newly emerged seedlings from surrounding cotton and melons (19). Leaf chlorosis and reduced head size have also been associated with colonization by $B$. tabaci on lettuce $(5,14)$.

There were no differences in the number of ELISA-positive heads in the insecticidetreated and the untreated lettuce plots during the September 1996 planted trial. This suggests that LCV was able to infect lettuce in the presence of imidacloprid. Duffus et al. (9) reported that LCV can be acquired within $1 \mathrm{~h}$ of feeding on an infected plant, suggesting that the insecticide requires a longer time to kill the whiteflies.

Variation in yield reductions in these trials was likely due to differences in the time of infection of the plants and the whitefly populations. The decrease in head weights between LCV-symptomatic and asymptomatic plants in combination with the lack of differences in average head weight between ELISA-positive and ELISA-negative heads suggest that only obviously symptomatic plants show a yield loss, and that asymptomatic virus-infected plants show little yield loss. This also suggests that given the difficulty in differentiating virus symptoms and whitefly feeding symptoms, yield losses detected in these trials may have been due to whitefly feeding damage.

Lettuce growers in the Imperial Valley of California routinely use imidacloprid for whitefly control. Our results suggest that the small yield increases gained through use of the insecticide are not economically justified given the price of lettuce and the cost of the insecticide.

Table 3. Influence of insecticide treatment on the percentage of lettuce chlorosis virus (LCV) symptomatic lettuce and yield in the 1996 planted trials $^{\mathrm{a}}$

\begin{tabular}{lccccc}
\hline & \multicolumn{2}{c}{ September planted } & & \multicolumn{2}{c}{ October planted } \\
\cline { 2 - 3 } \cline { 6 - 6 } Treatment & $\begin{array}{c}\text { Symptomatic } \\
\text { heads }(\boldsymbol{\%})\end{array}$ & $\begin{array}{c}\text { Mean head wt } \\
(\mathbf{g})\end{array}$ & & $\begin{array}{c}\text { Symptomatic } \\
\text { heads }(\boldsymbol{\%})\end{array}$ & $\begin{array}{c}\text { Mean head wt } \\
(\mathbf{g})\end{array}$ \\
\hline Imidacloprid & $0.5(0.3)^{\mathrm{b}}$ & $929.9(27)^{\mathrm{b}}$ & & 0.0 & $721.2(45)$ \\
Untreated & $2.1(0.2)$ & $605.5(52)$ & & 0.2 & $748.4(113)$ \\
\hline
\end{tabular}

${ }^{a}$ Mean of four blocks. Standard deviation is indicated in parentheses. Empire variety planted in September and Winterhaven variety planted in October.

b Treatment is significantly different from untreated control at $P=0.05$ using Fisher's LSD.

Table 2. Influence of insecticide treatment on the percentage of lettuce chlorosis virus (LCV) symptomatic lettuce and yield in the October 1995 planted trial $^{\mathrm{a}}$

\begin{tabular}{|c|c|c|c|c|c|c|}
\hline \multirow[b]{2}{*}{ Lettuce variety } & \multicolumn{3}{|c|}{ Plants with LCV symptoms (\%) } & \multicolumn{3}{|c|}{ Average head weight (g) } \\
\hline & Untreated & Imidacloprid & $\underset{\text { bifenthrin }}{\text { Imidacloprid }}+$ & Untreated & Imidacloprid & $\begin{array}{c}\text { Imidacloprid + } \\
\text { bifenthrin }\end{array}$ \\
\hline Acacia & $24.2(2)$ & $14.2(3)$ & $16.1(3)$ & 873.2 (109) & $967.3(58)$ & $1,095.4(56)^{\mathrm{b}}$ \\
\hline Empire & $23.5(4)$ & $14.7(4)$ & $14.8(5)$ & $895.8(22)$ & 949.1 ( 47$)$ & $1,076.1(73)^{\mathrm{b}}$ \\
\hline New Dominion & $24.6(5)$ & $11.1(1)$ & $10.0(4)$ & $1,072.7(76)$ & $1,117.0(65)$ & $1,208.8(146)$ \\
\hline Winterhaven & $24.8(3)$ & $11.0(3)$ & $9.9(2)$ & $1,064.8(41)$ & $1,107.9(133)$ & $1,147.6(78)$ \\
\hline Treatment means & $24.3(3)$ & $12.8(3)^{\mathrm{b}}$ & $12.8(4)^{\mathrm{b}}$ & $976.6(114)$ & $1,038.2(106)$ & $1,132.0(100)$ \\
\hline
\end{tabular}

a Mean of four blocks. Standard deviation is indicated in parentheses.

b Treatment is significantly different from untreated control at $P=0.05$ using Fisher's LSD. 


\section{LITERATURE CITED}

1. Bar-Joseph, M., and Hull, R. 1974. Purification and partial characterization of sugar beet yellows virus. Virology 62:552-562.

2. Candresse, T., and Martelli, G. P. 1995. Genus closterovirus. Pages 465-470 in: Virus Taxonomy Classification and Nomenclature of Viruses, Sixth Report of the International Committee on Taxonomy of Viruses. F. A. Murphy, C. M. Fauquet, D. H. L. Bishop, S. A. Ghabrial, A. W. Jarvis, G. P. Martelli, M. A. Mayo, and M. D. Summers, eds. SpringerVerlag, New York

3. Coffin, R. S., and Coutts, R. H. A. 1995. Relationships among Trialeurodes vaporariorum-transmitted yellowing viruses from Europe and North America. J. Phytopathol. 143:375-380.

4. Cohen, S., Duffus, J. E., and Liu, H. Y. 1992. A new Bemisia tabaci biotype in the southwestern United States and its role in silverleaf of squash and transmission of lettuce infectious yellows virus. Phytopathology 82:86-90.

5. Costa, H. S., Ullman, D. E., Johnson, M. W., and Tabashnik, B. E. 1993. Association between Bemisia tabaci density and reduced growth, yellowing, and stem blanching of lettuce and kai choy. Plant Dis. 77:969-972.

6. Creamer, R. 1992. Purification and protein characterization of sorghum stunt mosaic rhabdovirus. Phytopathology 82:1473-1476.

7. Creamer, R., and Falk, B. W. 1989. Characterization of a nonspecifically aphid-transmitted CA-RPV isolate of barley yellow dwarf virus. Phytopathology 79:942-946.
8. Duffus, J. E., Larsen, R. C., and Liu, H. Y. 1986. Lettuce infectious yellows virus-A new type of whitefly-transmitted virus. Phytopathology 76:97-100.

9. Duffus, J. E., Liu, H., Wisler, G., and Li, R. 1996. Lettuce chlorosis virus, a new whiteflytransmitted closterovirus. Eur. J. Plant Pathol. 102:591-596.

10. Gumpf, D. J., Bar-Joseph, M., and Dodds, J. A. 1981. Purification of citrus tristeza virus (CTV) on sucrose-cesium sulphate cushion gradients and estimation of its RNA size. (Abstr.) Phytopathology 71:878.

11. Klaassen, V. A., Boeshore, M., Dolja, V. V., and Falk, B. W. 1994. Partial characterization of the lettuce infectious yellows virus genomic RNAs, identification of the coat protein gene and comparison of its amino acid sequence with those of other filamentous RNA plant viruses. J. Gen. Virol. 75:15251533.

12. Klaassen, V. A., Boeshore, M. L., Koonin, E. V., Tian, T., and Falk, B. W. 1995. Genome structure and phylogenetic analysis of lettuce infectious yellows virus, a whitefly-transmitted, bipartite closterovirus. Virology 208:99110.

13. McMaster, G. K., and Carmichael, G. G. 1977. Analysis of single- and double-stranded nucleic acids on polyacrylamide and agarose gels by using glyoxal and acridine orange. Proc. Natl. Acad. Sci. USA 74:4835-4838

14. Palumbo, J. C., Kerns, D. L., Engle, C. E., Sanchez, C. A., and Wilcox, M. 1996. Imidacloprid formulation and soil placement effects on colonization by sweetpotato whitefly
(Homoptera:Aleyrodidae): Head size and incidence of chlorosis in lettuce. J. Econ. Entomol. 89:735-742.

15. Perring, T. M., Cooper, A. D., Rodriguez, R. J., Farrar, C. A., and Bellows, T. S. 1993 Identification of a whitefly species by genomic and behavioral studies. Science 259:74-77.

16. Sambrook, J., Fritsch, E. F., and Maniatis, T. 1989. Molecular Cloning: A Laboratory Manual. Cold Spring Harbor Laboratory, Cold Spring Harbor, NY.

17. Tian, T., Klaassen, V. A., Soong, J., Wisler, G., Duffus, J. E., and Falk, B. W. 1996. Generation of cDNAs specific to lettuce infectious yellows closterovirus and other whitefly-transmitted viruses by RT-PCR an degenerate oligonucleotide primers corresponding to the closterovirus gene encoding the heat shock protein 70 homolog. Phytopathology 86:1167-1173.

18. Valverde, R. A., Dodds, J. A., and Heick, J. A 1986. Double-stranded ribonucleic acid from plants infected with viruses having elongated particles and undivided genomes. Phytopathology 76:459-465.

19. Watson, T. F., Silvertooth, J. C., Tellez, A., and Lastra, L. 1992. Seasonal dynamics of the sweetpotato whitefly in Arizona. Southwest. Entomol. 17:149-167

20. Wisler, G. C., Liu, H.-Y., Klaassen, V. A Duffus, J. E., and Falk, B. W. 1996. Tomato infectious chlorosis virus has a bipartite genome and induces phloem-limited inclusions characteristic of the closteroviruses. Phytopathology 86:622-626. 